\title{
NOTES ON THE ROUGH-LEGGED HAWK IN THE PERRY RIVER REGION, NORTHWEST TERRITORIES
}

\author{
by Spencer G. Sealy, Dept. of Zoology, U.B.C., Vancouver
}

The Rough-legged Hawk (Buteo lagopus Pontoppidan) is a species of circumpolar distribution. During the breeding season in North America it is restricted to the tundra and to the tundra-forest. According to Cade (1955) three or four subspecies are currently recognized, B.l. sanctijohannis Gmelin being the breeding form of the American Arctic and Subarctic.

The data presented in this paper were obtained from July 8 to August 12,1965 , when the writer was assisting J. P. Ryder in Canadian Wildlife Service studies of Ross' Geese (Anser rossii) in the Perry River area, Northwest Territories $\left(67^{\circ} 42^{\prime}\right.$ N., $\left.102^{\circ} 15^{\prime} \mathrm{W}.\right)$. A study of the chronological events in the life history of this species was not made; however, fragmentary data were obtained from different nests during the duration of our stay and this information is supplemented by observations of other authors. A detailed description of the geography of the Perry River area is given by Hanson, et al (1956).

The American form of Buteo lagopus is said to be dimorphic or polymorphic (Cade, 1955), that is, there occurs a "light phase" and a "dark or melanistic phase" due to the degree of melanic pigmentation of the plumage. The Rough-leg shows a wide range of color variation from a nearly uniform sooty plumage to a light brown one. Gavin (1947) recorded only the "light phase" in the four years he spent in the Perry River area. Hanson, et al (1956) saw one "dark phase" bird among six pairs observed in 1949 and I saw three dark birds out of 45 seen in 1965 .

Gavin (1947), Hanson, etal (1956), Aleksiuk (1964) and Sealy (1966) all reported this species to be a common breeding bird in this area. Hanson, et al, thought "the nesting density of this species was probably about one pair for every 5-10 square miles of country" in 1949. The first arrival date in 1963, according to Aleksiuk (1964), was on May 22, the Rough-leg being one of the first species to arrive back from the wintering ground.

\section{Nesting Habits :}

Rough-legs breed on the open tundra, placing their nests on the steepest sides of Precambrian outcroppings. It is interesting to note that 30 per cent of the Rough-leg nests found (including three found by Hanson, et al, 1956), were placed on the colder, windswept, north-facing sides of the outcroppings (see Table 1). This selection may provide greater safety from predators, which could easily climb many of the gentler southfacing slopes.

The nests, constructed of branches of Arctic willow and Arctic birch, and lined with grasses, are bulky structures measuring on an average 30 inches by 18 inches in diameter and 10 inches in depth (four nests in sample). One nest was placed on top of four previously constructed nests.

TABLE 1. Nesting habits of the Roughlegged Hawk, Perry River, N.W.T., 1965.

\begin{tabular}{|c|c|c|}
\hline $\begin{array}{l}\text { Direction faced } \\
\text { by nest }\end{array}$ & $\begin{array}{l}\text { Number } \\
\text { of nests }\end{array}$ & $\begin{array}{l}\text { Per } \\
\text { cent }\end{array}$ \\
\hline North. & $6^{*}$ & 30.0 \\
\hline East.. & 4 & 20.0 \\
\hline South & 2 & 10.0 \\
\hline \multirow[t]{2}{*}{ West } & 8 & 40.0 \\
\hline & 20 & 100.0 \\
\hline \multicolumn{3}{|l|}{ Height of nest } \\
\hline 10 to 15 feet & 9 & 52.9 \\
\hline 16 to 20 feet & 2 & 11.8 \\
\hline 21 to 25 feet & 2 & 11.8 \\
\hline 26 to 35 feet & 1 & 5.9 \\
\hline \multirow[t]{2}{*}{36 to 45 feet } & 3 & 17.6 \\
\hline & $\overline{17}$ & 100.0 \\
\hline
\end{tabular}

* Sample includes three north-facing nests found by Hanson, et al (1956). 
Hanson, et al, found one nest "consisting of over ten different layers of willow twigs representing about as many successive annual nestings, perhaps by the same pair."

\section{Egg-Laying, Incubation and Brood Size:}

A nest containing one egg was found by Aleksiuk (1964) on June 6,1963 ; on June 15 , it contained five eggs. In the nests we observed, incubation was well under way when our party arrived on July 8, 1965. According to Burns (1915), the incubation period of the Rough-leg is 28 days.

The mean clutch in a sample of 17 nests was 3.3 with a range of two to five. In a sample of three nests in 1963, Aleksiuk (1964) recorded a mean clutch size of five with a range of four to six. The average number of downy young in 1965 was 2.8 per nest; the number successfully fledged is not known. The average hatching date for four nests in the Perry River area in 1965 was July 24 (range July 17-30). McEwen (1957) reported a clutch of Rough-legs hatching on July 8, 1950, at Bathurst Inlet, about 150 miles west of Perry River.

\section{Nesting Success:}

Fragmentary data are available from 17 nests though complete records concerning nesting success are lacking. These data are summarized in Table 2. Of 56 eggs laid, 48 or 85.7 per cent hatched (two nests containing three eggs and two eggs respectively, were deserted and three other nests each contained one unhatched egg). Due to our departure on August 12, fledging success data were not obtained, but it is thought that it would be comparable to the hatching success, for predation upon their young appeared to be negligible. Forty-three young were banded, the young being about three weeks old at the time of the banding, indicating mortality had not occurred up to this age (one nest with four young was inaccessible and a fourth young in another nest could not be reached).

\section{Food habits}

Observations showed the Parry's Ground Squirrel (Citellus parryii), Brown Lemming (Lemmus trimucro-
TABLE 2. Reproductive success of the Rough-leg, Perry River, N.W.T., 1965.

Number of nests 17

Eggs laid 56

Downy young

Average number of eggs per nest 3.3

Average number of young per nest

natus), and Collared Lemming (Dicrostonyx groenlandicus) were preyed upon by Rough-legs, with the Brown Lemming making up 83.3 per cent of all the mammalian food items found in their nests. Other available mammalian prey in the area were the Arctic Hare (Lepus arcticus) and the Red-backed Mouse (Clethrionomys rutilus). The Lapland Longspur (Calcarius lapponicus) was the only bird found in a nest (Sealy, 1965). Other available avian prey were numerous shorebirds, Horned Larks (Eremophila alpestris), American Pipits (Anthus spinoletta), Savannah Sparrows (Passerculus sandwichensis) and $\mathrm{S} n$ ow B u $\mathrm{n}$ in $\mathrm{g} \mathrm{s}$ (Plectrophenax nivalis).

McEwen reported that litter about the nests of Rough-legs found at Bathurst Inlet in 1950 "consisted mainly of lemming fur, bones of a caribou, dog, and ground squirrel, and a few feathers of snow bunting. Two lemmings were found below one nest. The size of the pellets were about one inch by three inches. They consisted mainly of lemming fur and bones."

\section{LITERATURE CITED}

Aleksiuk, M. 1964. Observations of birds and mammals in the Perry River region, N.W.T. Arctic, 17 (4) :263-267.

Burns, F. R. 1915. Comparative periods of deposition and incubation of some North American birds. Wilson Bull., $27: 275-286$.

Cade, T. J. 1955. Variation in the common Rough-legged Hawk in North America. Condor, $57(6): 313-346$.

Gavin, A. 1947. Birds of Perry River district, Northwest Territories. Wilson Bull., 59(4): 195-203.

Hanson, H. C., P. Queneau and P. Scott. 1956. The geography, birds and mammals of the Perry River region. Arct. Instit. of No. Am. Spec. Publ. No. 3, 92 pp.

McEwen, E. H. 1957, Birds observed at Bathurst Inlet, Northwest Territories. Can. FieldNat., 71 (3) :109-115.

Sealy, S. G. 1965. Interspecific nesting associations of some Arctic birds. Blue Jay, 23(4): 168-169.

Sealy, S. G. 1966. The Peregrine Falcon in the Perry River area, Northwest Territories. Bird-Banding in press. 